\title{
OESTROUS SYNCHRONIZATION AND OVARIAN ACTIVITY OF EWES TREATED WITH DIFFERENT HORMONAL TREATMENTS
}

\author{
Ashmawy, T. A. M. \\ Animal Production Research Institute
}

\begin{abstract}
Fourty ewes (1/2 Finnish Landrace - 1/2 Rahmani) were used. Animals were divided into 4 groups, 10 ewes each. Ewes of the $1^{\text {st }}$ group (G1, control) were bred naturally while those of the other three groups (G2, G3 and G4) undergun hormone treatment and were artificially inseminated. Ewes in G2 were i.m. injected with $4 \mu \mathrm{g}$ Buserelin (day 0), $175 \mu \mathrm{g}$ cloprostenol (day 7) and $4 \mu \mathrm{g}$ Buserelin (day 9), and artificially inseminated $24 \mathrm{~h}$ later. Ewes in G3 were intravaginally treated with $45 \mathrm{mg}$ FGA impregnated sponge for 11 days. Ewes in G4 were intravaginally treated (day 0) with Control Internal Drug Release (CIDR) for 11 days. Animals in G3 and G4 were i.m. injected with 600 IU PMSG 48 h before and $175 \mu$ cloprostenol (day 11) at device withdrawal, then artificially inseminated $52 \mathrm{~h}$ later.

Results showed that occurrence of oestrus was $30 \%$ in G2 and 100\% in each of G3 and G4. Oestrus occurred (in average) earlier after end of treatment in $G 3$ than in $G 2$ and G4. Estrous duration was similar in the three treatment groups. Lambing rate was similar between control, G3 and G4 (70\% in each) and was significantly $(P<0.05)$ higher than in $G 2$ (50\%).

It was concluded that synchronization of oestrus in ewes by applying controlled FGA or CIDR plus PMSG and $P G F_{2} \alpha$ might be a possibility to attain synchronized and early lambings in fall, to maximize the economic return.
\end{abstract}

Keywords: Ewes, oestrous synchronization, ovarian activity. 


\section{INTRODUCTION}

Controlled breeding is an important part of any breeding program to: a) improve lambing percentage; b) to have an even lamb croparound the year and c) greater return on ewe investment. Synchronization of oestrus and timing ovulation in sheep are considered to be a corner stone in formulating strategies for improving reproductive performance, planning of mating season and at some occasions to fit with the availability of feed resources.

According to Animal Production Research Institute, an accelerated lamb production system was based on mating in September, May and January using a 35-days mating period for 8 months lambing interval (3 lambings/2 years) (Aboul-Naga, 1988). A low fertility rate was observed in May breeding season represents the major constraint to this system. The problem usually occurrs during the first two weeks of May when ovarian activity in ewes of local breeds is still irregular. Extending the mating period increased fertility, but resulted in interrupted preparation of ewes for the following mating season (January).

Synchronization of oestrus is a tool with great potential to control breeding of small stock (Haresign, 1978). A variety of synchronization techniques had been used to induce oestrus in ewes (Cumming, 1979; Greyling and Van der Westhuysen, 1980), especially outside the normal breeding season (Bosu et al., 1978; Greyling et al., 1985).

The most commonly used method to synchronize oestrus during the breeding season is the progestagen impregnated intravaginal sponge, left in situ for 12-14 days (Gordon, 1983). Recently, several biotechnological methods have been developed to induce ovulation or synchronize oestrous activity in goats during the different months of the year (Aboul-

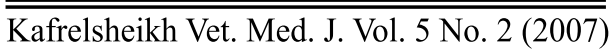


Ela et al. 2004) and to synchronize oestrous activity in sheep and goats during the breeding season (El-Saidy et al., 2005). Also, a recent study including Control Internal Drug Release (CIDR), and gonadotrophins + $\mathrm{PGF}_{2} \alpha$ were used for oestrous synchronization in ewes (McKusick et al., 2002).

Therefore, it was the objective of this study to evaluate the effect of using different hormonal treatments such as, GnRH-PGF $2 \alpha-G n R H$ protocol,Flugestone acetate(FGA-sponge)and CIDR on synchronization of oestrous and ovulation in ewes during May breeding season in an attempt to overcome the problem of low fertility and to detected the most effective and economic method of hormone treatment.

\section{MATERIALS AND METHODS}

The experimental work of this study was conducted on 1/2 Finnish Landrace - 1/2 Rahmani ewes at Sakha Animal Production Experimental Station. Fourty ewes weighting 45-50 kg and aging 3-4 years were used in this study. Ewes were divided into four similar groups 10 ewes each according to their body weight and age. Animals were fed concentrate feed mixture (14\% CP) and berseem hay according to NRC (1984).

Ewes of the control group (G1) were allowed for natural mating starting from May $1^{\text {st }}$. Ewes of the treatment groups were hormonally treated and artificially inseminated. Hormone treatments started by the last third of April to allow ewes to be inseminated early in May.

Ewes in the $2^{\text {nd }}$ group (G2) were injected i.m. (Day 0) with $1 \mathrm{ml}$ GnRH analogue, Receptal (Intervet International B.V. BoxmeerHolland). Each $1 \mathrm{ml}$ of Receptal contained $0.0042 \mathrm{mg}$ Buserelin acetate equivalent to $0.004 \mathrm{mg}$ Buserelin. Seven days later, each ewe was injected i.m with $0.7 \mathrm{ml}$ Estrumate (Coopers Animal Health LTD, 
Berkhansted, England). Each $1 \mathrm{ml}$ of Estrumate contained $263 \mu \mathrm{g}$ cloprostenol sodium equivalent to $250 \mu \mathrm{g}$ cloprostenol $\left(\mathrm{PGF}_{2} \alpha\right.$ analogue). A second dose of $1 \mathrm{ml} \mathrm{GnRH}$ analogue was given on day 9 and artificial insemination was carried out $24 \mathrm{~h}$ following the $2^{\text {nd }} \mathrm{GnRH}$ injection.

Ewes in the $3^{\text {rd }}$ group (G3) were treated with intravaginal sponges impregnated with $40 \mathrm{mg}$ Flugestone acetate (FGA, Intervet International B.V. Boxmeer-Holland). The sponge was inserted and remained intravaginal for 11 days. Each ewe was injected i.m. with 600 IU PMSG (Folligon, Intervet International B.V. Boxmeer-Holland) $48 \mathrm{~h}$ before sponge withdrawal (day 9) and $0.7 \mathrm{ml}$ Estrumate on the day of sponge withdrawal (Day 11) and the ewes were artificially inseminated at $52 \mathrm{~h}$ later.

Ewes in $4^{\text {th }}$ group (G4) were treated (day 0) with Controlled Internal Drug Release (CIDR type $\mathrm{G}$ device contained $0.3 \mathrm{~g}$ progetserone in inert silicone elastomer, Australian Distributor, Riverina Artificial Breeders Pty. Ltd.). The device remained intravaginal for 11 days. Ewes were i.m. injected with $600 \mathrm{IU}$ PMSG/ewe at $48 \mathrm{~h}$ before CIDR withdrawal (day 9) and 0.7 Estrumate on the day of CIDR withdrawal (day 11) and the ewes were artificially inseminated at $52 \mathrm{~h}$ after treatment.

\section{Oestrous detection:}

Starting from Estrumate injection in G2 group, and device withdrawal in groups G3 and G4, oestrus was detected four times daily (30 min. each) by using an aproned intact fertile ram. Data of the onset and duration of oestrus were recorded. 


\section{Insemination:}

Semen was collected from proven fertile rams by artificial vagina and diluted just before insemination. Semen was extended with Tris-yolk extender. Each $100 \mathrm{ml}$ of Tris-yolk extender consisted of $3.025 \mathrm{~g}$ Tris, $1.675 \mathrm{~g}$ citric acid, $0.75 \mathrm{~g}$ glucose, $15 \mathrm{ml}$ egg yolk, 100.000 IU Penicillin and $100.000 \mu \mathrm{g}$ Streptomycin and distilled water up to $100 \mathrm{ml}$. Immediately after semen collection, the volume was measured and subsample of raw semen was tested for sperm motility according to the method described by Bane (1982). Only ejaculates with $80-90 \%$ initial motility were extended ( 1 part semen plus 4 parts extender) at $37^{\circ} \mathrm{C}$. Sperm concentration was estimated and adjusted in the extender to be about $300 \times 10^{6}$ total sperm $/ \mathrm{ml}$ extended semen.

Insemination was carried out using a simple plastic disposable inseminating pipettes with fine blunt bent end and a vaginal speculum. One $\mathrm{ml}$ of extended semen was deposited into the cervix as far as possible.

\section{Blood sampling:}

Blood samples were taken from all the experimental animals via the jugular vein at 8.30 a.m. into evacuated heparinized tubes $(10 \mathrm{ml})$ as shown in timetabled.

\begin{tabular}{|c|c|c|c|c|c|c|c|c|c|c|c|c|c|c|c|c|c|}
\hline \multirow[t]{2}{*}{ G1: } & Control & \multicolumn{16}{|c|}{ Twice weekly for 7 weeks starting from hormone treatment. } \\
\hline & & & G & & & & PG & & G & $\mathrm{AI}$ & & & \multicolumn{2}{|c|}{ days } & & & \\
\hline G2: & GnRH & -2 & 0 & 2 & 4 & 6 & 7 & 8 & 9 & 10 & 11 & 12 & 13 & 14 & 15 & 22 & 29 \\
\hline & & & I & & & & PM & & \multicolumn{2}{|c|}{$\mathrm{R}+\mathrm{PG}$} & AI & & \multicolumn{2}{|c|}{ days } & & & \\
\hline G3: & FGA & -2 & 0 & 3 & 7 & 8 & 9 & 10 & 11 & 12 & 13 & 14 & 15 & 22 & 29 & & \\
\hline G4: & CIDR & -2 & 0 & 3 & 7 & 8 & 9 & 10 & 11 & 12 & 13 & 14 & 15 & 22 & 29 & & \\
\hline
\end{tabular}

( $\mathrm{G}=\mathrm{GnRH}, \mathrm{PG}=\mathrm{PGF}_{2} \alpha, \mathrm{I}=$ insertion, $\mathrm{PM}=\mathrm{PMSG}, \mathrm{R}=$ removal and $\mathrm{AI}=$ artificial insemination) 


\section{Progesterone hormone assay:}

Plasma progesterone hormone concentration was determined by radioimmunoassay procedure in samples of 5 selected animals (3 lambed ewes and two non-lambed ewes) in all groups. Quantitative determination of progesterone in plasma samples was carried out using progesterone radioimmunoassay kit (Catalog No. 1188 manufactured by Immunotech, France). The assay is based on competition reaction (Bojanic et al., 1991).

\section{Statistical analysis:}

Data were analyzed using $\boldsymbol{S A S}$ (1999), GLM analysis of variance for oestrous duration and litter size and Chi-squares for the occurance of oestrus and lambing rates. Duncan Multiple Range test (Duncan, 1955) was used to detect the significance between treatment groups.

\section{RESULTS AND DISCUSSION}

\section{Oestrous activity:}

\section{Occurrence of oestrus:}

Data in table (1) represent oestrous occurrence in ewes following treatment. Data showed complete response (100\%) of ewes to FGAsponge and CIDR treatments. On the other hand, using GnRH protocol resulted in significantly lower $(\mathrm{P}<0.01)$ oestrous occurrence $(30 \%)$.

Table(1):Oestrous occurrence and frequency distribution of the onset of oestrus in responding ewes of the different treatment groups.

\begin{tabular}{|c|c|c|c|c|c|c|c|c|c|c|c|c|}
\hline \multirow{3}{*}{ Group } & \multirow{3}{*}{$\mathbf{n}$} & \multirow{2}{*}{\multicolumn{2}{|c|}{$\begin{array}{l}\text { Ewes came } \\
\text { in oestrus }\end{array}$}} & \multicolumn{9}{|c|}{ Onset of oestrus (h) } \\
\hline & & & & \multirow{2}{*}{$\begin{array}{c}\text { Average } \\
\pm \mathrm{SE}\end{array}$} & \multicolumn{2}{|c|}{32} & \multicolumn{2}{|c|}{36} & \multicolumn{2}{|c|}{40} & \multicolumn{2}{|c|}{44} \\
\hline & & $\mathbf{n}$ & $\%$ & & $\mathbf{n}$ & $\%$ & $\mathbf{n}$ & $\%$ & $\mathbf{n}$ & $\%$ & $\mathbf{n}$ & $\%$ \\
\hline $\mathrm{GnRH}$ & 10 & 3 & $30^{\mathrm{B}}$ & $38.66 \pm 1.33$ & - & - & 1 & 33.3 & 2 & $66.7^{\mathrm{a}}$ & - & - \\
\hline FGA & 10 & 10 & $100^{\mathrm{A}}$ & $36.80 \pm 1.55$ & 4 & $40^{\mathrm{a}}$ & 2 & 20 & 2 & $20^{b}$ & 2 & $20^{b}$ \\
\hline CIDR & 10 & 10 & $100^{\mathrm{A}}$ & $39.20 \pm 1.55$ & 2 & $20^{\mathrm{b}}$ & 2 & 20 & 2 & $20^{\mathrm{b}}$ & 4 & $40^{\mathrm{a}}$ \\
\hline
\end{tabular}

$\boldsymbol{A}$ and $\boldsymbol{B}$ : Means denoted within the same column with different superscripts are significantly different at $(\mathrm{P}<0.01)$.

$\boldsymbol{a}$ and $\boldsymbol{b}$ : Means denoted within the same column with different superscripts are significantly different at $(\mathrm{P}<0.05)$.

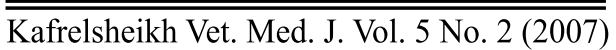


Using the same GnRH protocol during September mating season in ewes of the same breed group, resulted in $25 \%$ occurrence of estrus (ElSaidy et al., 2005). Comparing among treatments, Ungerfeld et al. (1999) found differences between FGA and CIDR treatments in oestrous response (35 and 50\%, respectively) of Corriedale ewes during the nonbreeding season.

\section{Onset of oestrus:}

Data in Table (1) indicated insignificant differences between treatments in the onset of oestrus. Oestrus occurred earlier in FGA (36.80 h) than in GnRH (38.66 h) and CIDR (39.20 h) groups.

Using the same GnRH protocol in ewes of the same breed group during the breeding season, El-Saidy et al. (2005) found similar values for the onset of oestrus.

\section{Duration of oestrus (h):}

Data in Table (2) show similar average duration of oestrus in GnRH, FGA and CIDR groups (20 h). Duration of oestrus in all groups ranged between 16 and $24 \mathrm{~h}$. Data also show that $40 \%$ of the ewes in each of FGA and CIDR groups stayed in oestrus for $20 \mathrm{~h}$. The rest of ewes in each group were equally distributed (30\% each) to have a duration of oestrus of 16 and $24 \mathrm{~h}$, respectively.

Table (2): Duration of oestrus and its frequency distribution in responding ewes of the different treatment groups.

\begin{tabular}{|c|c|c|c|c|c|c|c|c|c|}
\hline \multirow{3}{*}{ Group } & \multirow{2}{*}{\multicolumn{2}{|c|}{$\begin{array}{c}\text { Ewes came in } \\
\text { oestrus }\end{array}$}} & \multirow{3}{*}{ average $\pm \mathrm{SE}$} & \multicolumn{6}{|c|}{ Duration of oestrus (h) } \\
\hline & & & & \multicolumn{2}{|c|}{16} & \multicolumn{2}{|c|}{20} & \multicolumn{2}{|c|}{24} \\
\hline & $\mathbf{n}$ & $\%$ & & $\mathbf{n}$ & $\%$ & $\mathbf{n}$ & $\%$ & $\mathbf{n}$ & $\%$ \\
\hline$\overline{\mathrm{GnRH}}$ & $\overline{3}$ & $30^{\mathrm{B}}$ & $20.0 \pm 2.31$ & 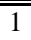 & $10^{\mathrm{b}}$ & 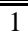 & $10^{\mathrm{b}}$ & 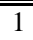 & $\overline{10 \mathrm{~b}}$ \\
\hline FGA & 10 & $100^{\mathrm{A}}$ & $20.2 \pm 1.03$ & 3 & $30^{\mathrm{a}}$ & 4 & $40^{\mathrm{a}}$ & 3 & $30^{\mathrm{a}}$ \\
\hline CIDR & 10 & $100^{\mathrm{A}}$ & $20.0 \pm 1.03$ & 3 & $30^{\mathrm{a}}$ & 4 & $40^{\mathrm{a}}$ & 3 & $30^{\mathrm{a}}$ \\
\hline
\end{tabular}

$\boldsymbol{A}$ and $\boldsymbol{B}$ : Means denoted within the same column with different superscripts are significantly different at $(\mathrm{P}<0.01)$. 
Using the same GnRH protocol, a longer oestrous duration $(28 \mathrm{~h})$ was reported in ewes of the same breed group during the breeding season (El-Saidy et al., 2005). Despite of the wide variability in the reviewed data of oestrus in ewes due to breed, season and treatment, oestrous duration varied due to synchronization with $\mathrm{PGF}_{2} \alpha$ or administration of progestagen together with PMSG, which lengthen oestrus by about $6 \mathrm{~h}$ compared with natural cycles (Greyling and Van Niekerk, 1990).

\section{Lambing rate and litter size:}

Lambing has been considrered as referring to conception. Data in Table (3) show an equal lambing rate (70\%) for the control, FGA and CIDR groups. This value is significantly $(\mathrm{P}<0.05)$ higher than that of the GnRH group (50\%). It is worthy noting that at least 2 out of 7 ewes $(28.5 \%)$, which did not show oestrus following GnRH treatment lambed due to blind insemination. This means that at least $20 \%$ of the ewes treated with GnRH had silent ovulation. On the other hand, $30 \%$ of the ewes showed estrus in FGA and CIDR groups failed to conceive after insemination following the hormonal treatment.

Table (3): Lambing rate and litter size in ewes of the different experimental groups.

\begin{tabular}{|c|c|c|c|c|c|c|c|}
\hline \multirow{3}{*}{ Group } & \multirow{3}{*}{$\begin{array}{c}\text { Total } \\
\text { No. }\end{array}$} & \multicolumn{4}{|c|}{ Ewes lambed } & \multirow{3}{*}{ No. of lambs born } & \multirow{3}{*}{ Litter size } \\
\hline & & \multirow{2}{*}{$\mathbf{R}$} & \multirow{2}{*}{ NR } & \multicolumn{2}{|c|}{ Total } & & \\
\hline & & & & $\mathbf{n}$ & $\%$ & & \\
\hline Control & 10 & 7 & - & 7 & $70^{\mathrm{a}}$ & 9 & 1.3 \\
\hline GnRH & 10 & 3 & 2 & 5 & $50^{b}$ & 6 & 1.2 \\
\hline FGA & 10 & 7 & - & 7 & $70^{\mathrm{a}}$ & 10 & 1.4 \\
\hline CIDR & 10 & 7 & - & 7 & $70^{\mathrm{a}}$ & 10 & 1.4 \\
\hline
\end{tabular}

a, b.....d: Means denoted within the same column with different superscripts are significantly different at $(\mathrm{P}<0.05)$.

$\mathbf{R}=$ Number of ewes which have came in oestrus.

$\mathbf{N R}=$ Number of ewes which have not shown oestrus .

$\overline{\text { Kafrelsheikh Vet. Med. J. Vol. } 5 \text { No. } 2 \text { (2007) }}$ 
If insemination is supposed to be based on the overt signs of oestrus, lambing rate in ewes in GnRH group will reach maximum value of $30 \%$. These results support the practicability and feasibility of the procedure of pre-determined time as a base for implementation of insemination rather than dependence on the occurrence of oestrus (Table 3).

In agreement with the present fertility results, Ungerfeld et al. (1999) found no significant differences between treatment with FGA and CIDR device in conception rate of Corriedale ewes during non-breeding season. Also, the pregnancy rate of Merino ewes during the breeding season was similar for FGA-30 mg, FGA-40 mg sponge and CIDR-G being 74.7, 72.1 and 71.7\%, respectively (Hill et al., 1998). Ewes treated during the breeding season with CIDR and naturally mated had conception rate of $74.1 \%$ (Godfrey et al., 1997).

Beck et al. (1996) reported that there was no effect due to treatment on lambing performance $(\%)$ when ewes were treated with either GnRH plus $\mathrm{PGF}_{2} \alpha(88 \%)$ or a double dose of $\mathrm{PGF}_{2} \alpha(92.5 \%)$ to synchronize oestrus during the breeding season.

Concerning the litter size of ewes (Table 3), as compared to the control group (1.3) treatment with FGA and CIDR resulted in higher litter size (1.4), while litter size in GnRH group was lower (1.2).

Increasing litter size of ewes in FGA and CIDR groups may be referred to PMSG dose (600 IU/ewe) which might be high for the local crossbred sheep during this time of the year. Ritar et al. (1989) advised the use of a lower dose of PMSG (200 IU) when it is combined with CIDR or sponge treatment to avoid increasing litter size and subsequently high rates of post-natal mortality during the breeding season. 
In Welsh Halfbred (Beck et al. 1996) ewes treated with GnRH (4 $\mu \mathrm{g}$ Buserelin) followed, 5 days later by $100 \mu \mathrm{g} \mathrm{PGF} 2 \alpha$, litter size was 1.69. The differences among studies in litter size could be referred to differences in treatment, dose of PMSG, season and breed.

\section{Progesterone profile:}

Progetseropne $\left(\mathrm{P}_{4}\right)$ profile in the sampled ewes of the control and treatment groups pre-, during and post-treatment is presented in Figures (2-5).

\section{Control group:}

Average $\mathrm{P}_{4}$ concentration in control ewes was at the basal level in non-pregnant ewes ranging between 0.018 and $0.544 \mathrm{ng} / \mathrm{ml}$ during the period from 22 April up to 13 June. In pregnant ewes, average level started to increase from $0.224 \mathrm{ng} / \mathrm{ml}$ (average 9 May) to reach the maximum level $(1.668 \mathrm{ng} / \mathrm{ml})$ at 20 May on average, thereafter, $\mathrm{P}_{4}$ declined to $0.198 \mathrm{ng} / \mathrm{ml}$ at 27 May (Ovulation and conception) and increased again reaching $2.671 \mathrm{ng} / \mathrm{ml}$ by day 16 of pregnancy (Fig. 1). The $\mathrm{P}_{4}$ plateau preceding pregnancy indicates the occurrance of silent ovulation during the $1^{\text {st }}$ half of May.

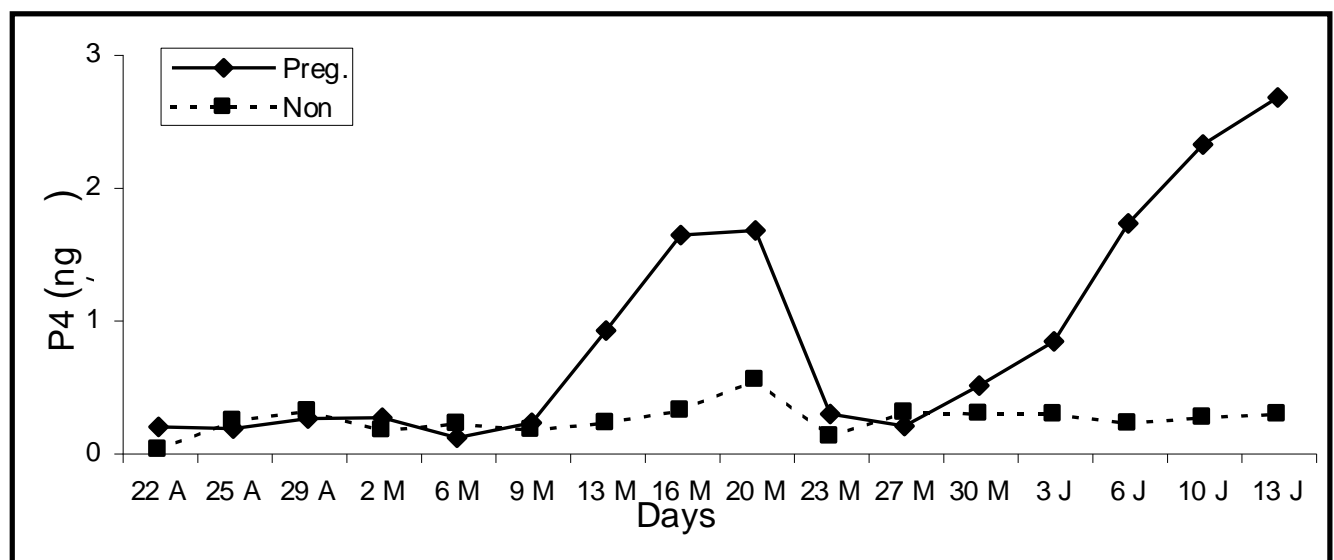

Fig. (1): Changes in P4 concentration in control ewes during April (A) and May (M) months. 


\section{GnRH group:}

In GnRH group, the trend of change in level of $\mathrm{P}_{4}$ pre-, during and 4 days post-treatment was the same in both pregnant and non-pregnant ewes. It showed marked increase after $1^{\text {st }} \mathrm{GnRH}$ (day 0) injection to reach maximum levels $(0.7-0.9 \mathrm{ng} / \mathrm{ml})$ on days 5,6 and 7 , then decreased to less than $0.5 \mathrm{ng} / \mathrm{ml}$ on days 9 and 10. Thereafter, light and slow increase in the level of $\mathrm{P}_{4}$ started in all ewes. In pregnant ewes, the increase in $\mathrm{P}_{4}$ level continued and got faster from day 15 to reach 2.7 $\mathrm{ng} / \mathrm{ml}$ on day 29, while $\mathrm{P}_{4}$ decreased in non-pregnant ewes from 0.53 $\mathrm{ng} / \mathrm{ml}$ on day 13 toward the basal level. $\mathrm{P}_{4}$ level in one of the two nonpregnant ewes reached 0.5 and $0.7 \mathrm{ng} / \mathrm{ml}$ on days 12 and 13, respectively. According to Gordon (1996) the failure of conception in such ewe could be referred to insufficient corpora luteau. This ewe was considered as ovulating (Fig. 2).

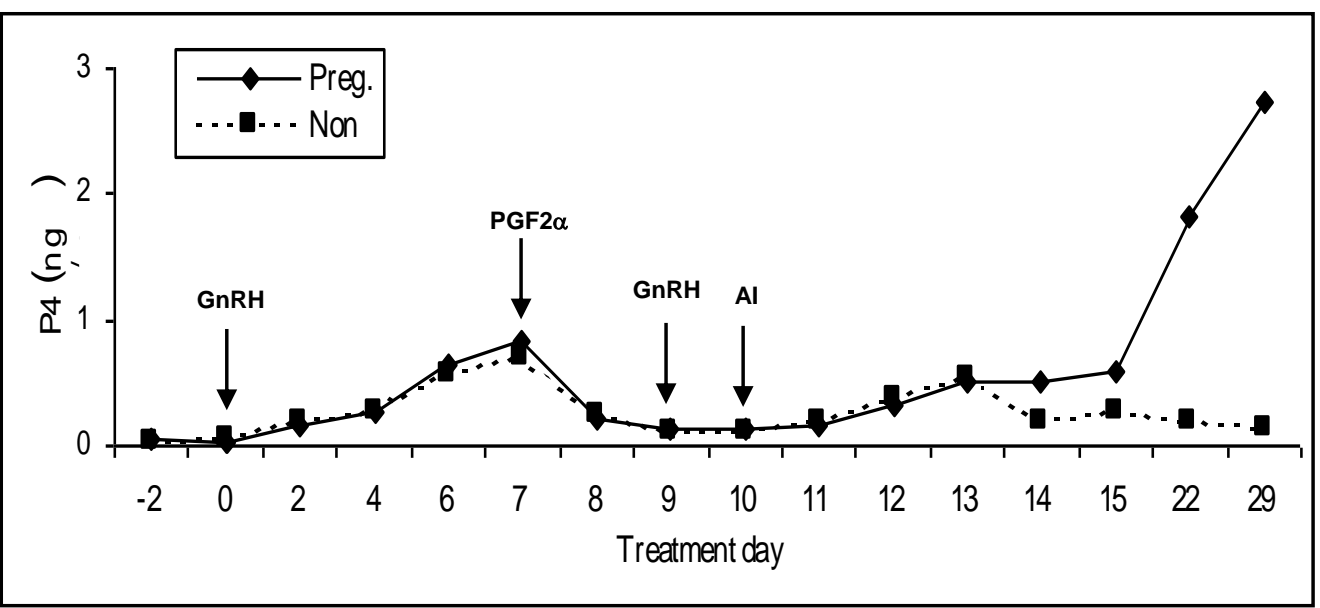

Fig. (2): Changes in $\mathrm{P} 4$ concentration in ewes of GnRH group. 


\section{FGA group:}

In FGA group, $\mathrm{P}_{4}$ levels on the day before and day of treatment were basal in both pregnant ( 0.155 and $0.242 \mathrm{ng} / \mathrm{ml}$, respectively) and non-pregnant ewes (0.057 and 0.074, respectively). Level of $\mathrm{P}_{4}$ started to increase gradually after sponge insertion to reach the maximum level (6.863 and $6.710 \mathrm{ng} / \mathrm{ml}$ in pregnant and non-pregnant ewes, respectively) on day 10 after $24 \mathrm{~h}$ of PMSG injection (day 9). On the day of sponge withdrawal and $\mathrm{PGF}_{2} \alpha$ injection (day 11) of treatment, level of $\mathrm{P}_{4}$ began to show sharp reduction to reach levels of $0.160 \mathrm{ng} / \mathrm{ml}$ in pregnant and $0.166 \mathrm{ng} / \mathrm{ml}$ in non-pregnant ewes on day 13 (insemination). Level of $\mathrm{P}_{4}$ remained low in the non-pregnant while it started fast increase from day 15 reaching $3.527 \mathrm{ng} / \mathrm{ml}$ on day $29 . \mathrm{P}_{4}$ profile in the non-pregnant ewes means absence of ovulation, which could be considered as the reason of failure of pregnancy (Fig. 3).

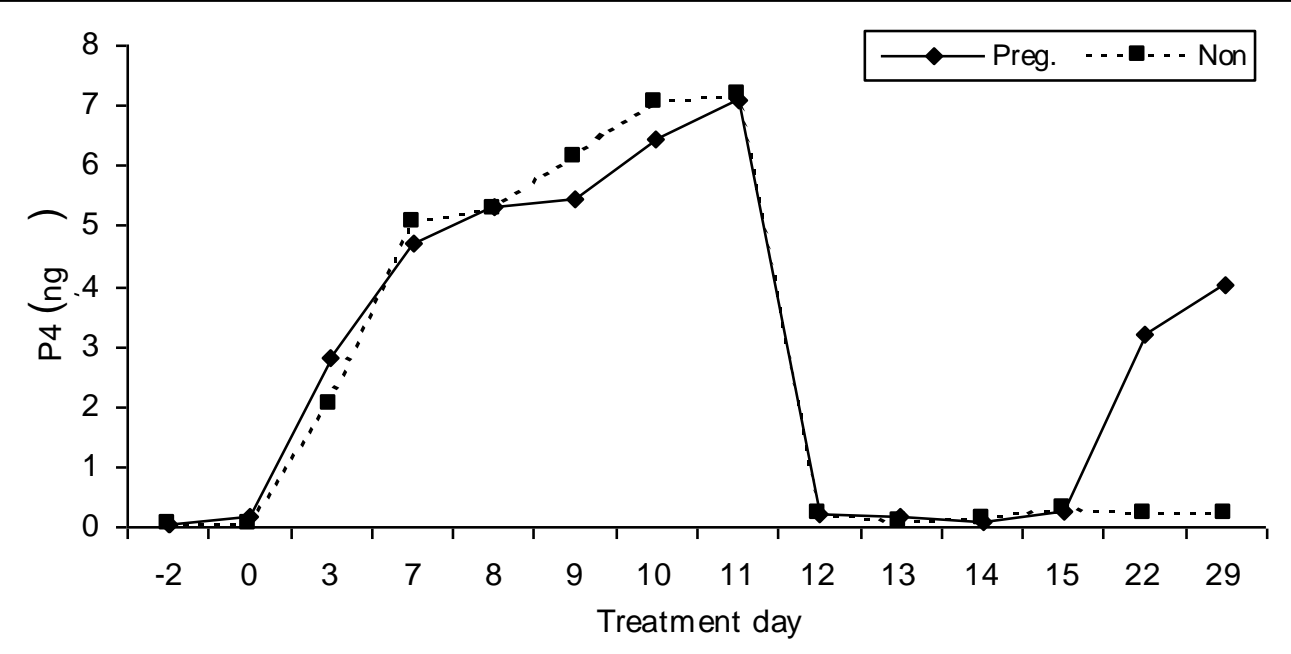

$\overline{\overline{\text { Kafrelsheikh Vet. Med. J. Vol. } 5 \text { No. } 2 \text { (2007) }}}$ 
Fig. (3): Changes in P4 concentration in ewes of FGA-sponge group.

\section{CIDR group:}

$\mathrm{P}_{4}$ profile in this group followed the same trend as in the FGAgroup both in pregnant and non-pregnant ewes. Again the failure of pregnancy could be referred to failure of ovulation (Fig. 4).

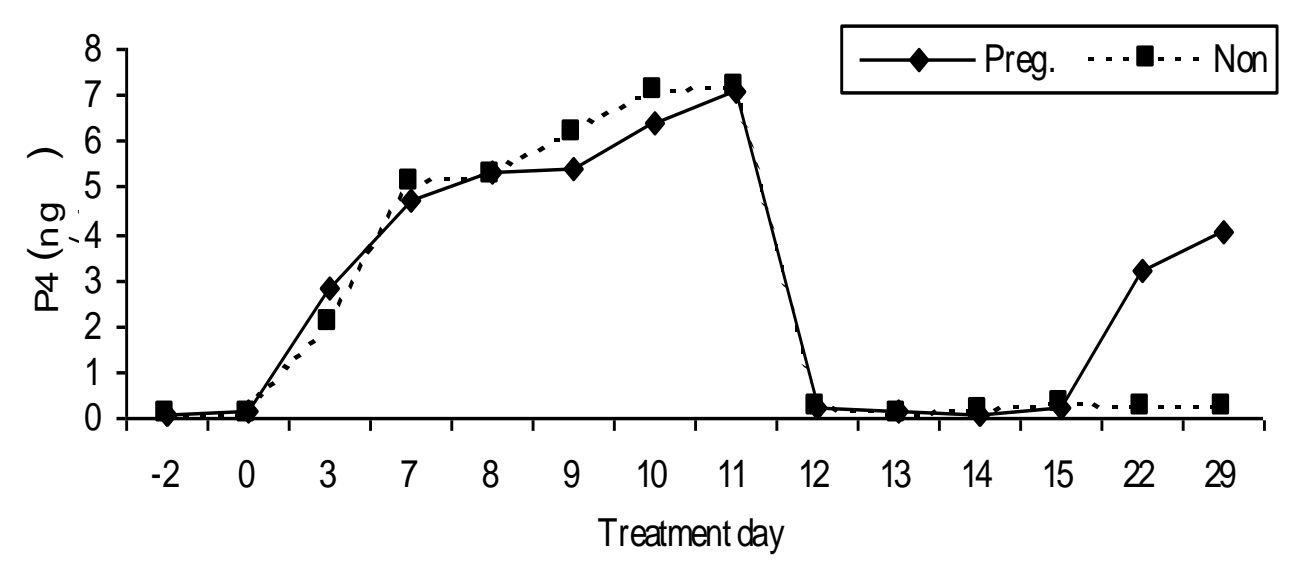

Fig. (4): Changes in $\mathrm{P}_{4}$ concentration in ewes of CIDR group.

Increasing level of $\mathrm{P}_{4}$ in ewes during FGA and CIDR treatments reflect mainly the eefect of exogenous progestine in both protocols. The maximum $\mathrm{P}_{4}$ level in treated ewes with both protocols have been attained at the last day of treatment (day 11). Basal level was detected the days followed the end of treatment. More accurate time for $\mathrm{P}_{4}$ to reach the basal level following treatment in sheep has been reported by Ritar et al. (1984 and 1989) as $6.8 \mathrm{~h}$ for FGA and by Barnes (1987) as $6.5 \mathrm{~h}$ for CIDR treatment. 
In both pregnant and non-pregnant ewes in FGA and CIDR groups, it was observed higher $\mathrm{P}_{4}$ level during treatment days. The main cause of the failure of pregnancy following FGA or CIDR might be the failure of ovulation. The cause of failure of ovulation is in need of explanation.

\section{Lambing synchrony and subsequent fertility:}

Onset and duration of lambing season for ewes in each of the experimental groups are shown in Table (4). Results in the table indicated average 12-14 days early in the lambing season for treated than in control ewes. Moreover, duration of the lambing season represented in treatment groups less than $20 \%$ of that in the control group (7 days in each of treatment groups compared with 37 days in controls). When the experimental ewes were allowed for the natural mating in the next season (January) according to the managerial production system of APRI (3 lambings/2 years), only $50 \%$ of the control ewes have been conceived compared with 70, 70 and $60 \%$ conception rate in those of GnRH, FGA and CIDR groups, respectively. This could be considered as reasonable reflection of the wide range of lambing dates in the control group compared with that in each of the treatment groups. In other words, treatment for synchronization of estrous/ovulation resulted in subsequent synchronized and early lambing than in controls which, in turn, followed by earlier weaning and better chance for getting ready for the next mating season (January).

Table (4): Lambing synchrony and subsequent fertility.

\begin{tabular}{|c||c||c|}
\hline Group & Lambing season & Subsequent fertility \\
\hline
\end{tabular}




\begin{tabular}{|l||c|c|c||c||}
\hline \hline \hline & Average date & $\begin{array}{c}\text { Range } \\
\text { (from - to) }\end{array}$ & $\begin{array}{c}\text { Duration } \\
\text { (d) }\end{array}$ & rate (\%) \\
\hline \hline Control & Oct. $18^{\text {th }}$ & $3 / 10-8 / 11$ & 37 & 50 \\
GnRH & Oct. $6^{\text {th }}$ & $3 / 10-9 / 10$ & 7 & 70 \\
FGA & Oct. $5^{\text {th }}$ & $2 / 10-8 / 10$ & 7 & 70 \\
CIDR & Oct. $4^{\text {th }}$ & $2 / 10-8 / 10$ & 7 & 60 \\
\hline \hline
\end{tabular}

\section{Economic return of treatment:}

According to the cost of hormonal treatment presented in table (5), $\mathrm{GnRH}$ represented the cheapest treatment but the output of this treatment was low (6 lambs) as compared with FGA and CIDR treatments (10 lambs each). The treatment cost/lamb born was 16.7, 38 and 38 L.E. for the three treatment groups, respectively.

Table (5): Treatment costs of different hormonal treatment.

\begin{tabular}{||l||c||c|c||c||c||}
\hline Groups & N & $\begin{array}{c}\text { Treeatment } \\
\text { cost/ewe (LE) }\end{array}$ & $\begin{array}{c}\text { Total treatment } \\
\text { costs (LE) }\end{array}$ & $\begin{array}{c}\text { No. lambs } \\
\text { born }\end{array}$ & $\begin{array}{c}\text { Treatment cost/lamb } \\
\text { born (LE) }\end{array}$ \\
\hline \hline GnRH & 10 & 10 & 100 & 6 & 16.7 \\
FGA & 10 & 38 & 380 & 10 & 38 \\
CIDR & 10 & 38 & 380 & 10 & 38 \\
\hline
\end{tabular}

\section{CONCLUSIONS}

Within the sheep production system of 3 lambing/2 years in Animal Production Research Institute, mating in May and January seasons usually gains lower fertility rates compared with that in September.

January is followed by a period of irregular and low estroius activity in local breeds of sheep terminates by early May. So, the majority of ewes would not naturally mated by the first half of May and 
conception rates, in turn, will be low unless the mating season is extended behind May.

Results of the present study indicated late incidence of pregnancy due to natural mating in May (control group) resulting in delay of lambing (average date October $18^{\text {th }}$ ) and long duration of lambing season ( 37 days, from October $3^{\text {rd }}$ to November $8^{\text {th }}$ ). This led to delay in weaning of lambs and consequent low fertility rate $(50 \%)$ due to the subsequent mating season (January). On the other hand, hormonal treatment resulted in synchronized and early lambing which allowed enough time for preperation to January natural mating season and consequential relatively high fertility rates. These results could justify the lamb production extracosts paid for hormonal treatment. Exceptionally, within hormonal treatment groups, GnRH compared with FGA and CIDR protocols, albeit much less costing, resulted in marked low lamb production and it is unreasonable to be recommended.

Progesterone profile in the studies ewes during and post $\mathrm{GnRH}$ treatment indicated immature CL as a main and direct cause of the failure of pregnancy. This leads to the need for more investigation with the trial of modifying GnRH treatment protocol in terms of dose and dosage interval and studying the simulateneous folloicular dinamics.

An indicated cause of conception failure in FGA and CIDR treated ewes is the absence of ovulation. Prolonging pessary stay intravaginal may cover such cause and result in better response.

\section{REFERENCES}

- Aboul-Ela, M. B. ; A. E. Abdel-Khalek ; M. G. Gabr and T. A. M. Ashmawy (2004). Oestrous activity of Damascus does 
treated with $\mathrm{GnRH}-\mathrm{PGF}_{2} \alpha-\mathrm{GnRH}$ protocol during different months of the year. J. Agric. Sci. Mansoura Univ. 29(9): 48754886.

- Aboul-Naga, A. M. (1988). Implementation of intensive lamb production systems: incorporation of native breed and maximizing the utilization of their potentials. Small Ruminants Research and Development in the Near East. Proceeding of a workshop Held in Cairo, Egypt, 2-4 Nov.

- Bane, A. A. (1982). Study on the technique of hemocytometric determination of sperm motility and sperm concentration in bull semen. Cornell Vet., 42: 518-528.

- Barnes, D. R. (1987). CIDR dispensers-ewe and hogget plasma progesterone levels during the insertion period. Proc. $4^{\text {th }}$ AsianAustralian Assoc. Anim. Prod. Soc., Animal Science Congress, Hamilton, New Zealand, p. 228.

- Beck, N. F. G. ; M. Jones ; B. Davies ; A. R. Peters and S. P. Williams (1996). Oestrus synchronization in ewes: the effect of combining a prostaglandin analogue with a $\mathrm{GnRH}$ agonist (buserelin). Animal Sci., 62: 85-87.

- Bojanic, S. ; R. Lake ; J. Place ; L. Jones ; J. Laycoock ; G. Carter and J. Alagh-Band-Zadeh (1991). Serum progesterone concentration is raised during early follicular phase in women with polycystic ovaries. Ann. Clin. Biochem., 28: 105-106. 
- Bosu, W. T. K. ; J. Serna and C. A. V. Barker (1978).

Peripheral plasma levels of progesterone in goats treated with fluorogestone acetate and prostaglandin F2 $\alpha$ during the estrus cycle. Theriogenology, 9: 371-375.

- Cumming, I. A. (1979). Synchronization of ovulation. In: G. J. Tomes, D. E. Robertson and R. J. L. Lightfoot (Editors), sheep breeding. Butterworths, London, 403-421.

- Duncan, D. B. (1955). T-test and interval for comparison suggested by the date. Biometrics, 31: 339-359.

- El-Saidy, B. E. ; A. E. Abdel-Khalek; T. A. M. Ashmawy and M. G. Gabr (2005). Synchronization of ovulation in ewes and does following GnRH-PGF2 $\alpha-G n R H$ protocol and time of insemination. The 4th International Scientific Conference, Mansoura 5-6 April : 201-212 .

- Godfrey, R. W. ; M. L. Gray and J. R. Collins (1997). A comparison of two methods of oestrous synchronization of hair sheep in the tropics. Anim. Reprod. Sci., 47(1-2): 99-106.

- Gordon, I. (1983). In controlled breeding in farm animals (ed. I. Gordon), pp. 181-195. Permagon Press, London.

- Gordon, I. (1996). Controlled reproduction in sheep and goat. Dublin, Ireland. pp. 375-397.

- Greyling, J. P. C. and J. M. Van der Westhuysen (1980). The 
synchronization of oestrus in sheep. 3- The use of intravaginal progestagen and/or prostaglandin. S. Afr. J. Anim. Sci., 10: 6568.

- Greyling, J. P. G. ; C. H. Van Niekerk and J. A. N. Grobbelaar (1985). Synchronization of oestrus in the Boer goat doe: the response to the use of intravaginal progestagen and PMSG. S. Afr. J. Anim. Sci., 15: 52-55.

- Greyling, J. P. C. and C. H. Van Niekerk (1990). Ovulation in the Boer goat doe. Small Ruminant Research, 3: 457-464.

- Haresign, W. (1978). Ovulation control in sheep. In D. B. Crighton, N. B. Haynes, G. R. Foxcroft and G. E. Lamming (Editors), control of ovulation. $1^{\text {st }}$ Edn. Butterworths, London, 435-451.

- Hill, J. R. ; J. A. Thompson and N. R. Perkins (1998). Factors affecting pregnancy rates following laparscopic insemination of 28, 447 Merino ewes under commercial condition. A survey. Theriogenology, 49(4): 697-709.

- NRC (1984). Nutrient Requirements of Sheep. (6th Ed.) National Academy press, Washington, DC.

- Ritar, A. J. ; W. M. C. Maxwell and S. Salamon (1984). Ovulation and LH secretion in the goat after interavaginal progestagen sponge-PMSG treatment. J. Reprod. Fertil., 72: $559-563$. 
- Ritar, A. J. ; S. Salamon ; P. D. Ball and P. J. O'May (1989).

Ovulation and fertility in goats after interavaginal devicePMSG treatment. Small Ruminant Research 2: 323-331.

- SAS/STAT (1999). Guide for personal computers. Version 8 Ed. Cary NC, USA, SAS Institute.

- Ungerfeld, R. ; A. Pinczak ; M. Forsberg and E. Rubianes (1999). Response of Corriedale ewes to the "ram effect" after priming with medroxy-progesterone, fluorogestone, or progesterone in the non-breeding season. Acta Vet. Scand, 40(4): 299-305. 
تنظيم الثبق و النشاط المبيضى فى النعاج باستخدام معاملات هرمونية مختلفة د./طارق عشعاوى محمود عشماوى

\section{معه بحوث الإنتاج الحيوانى}

استخدم فى هذه الدراسـة 40 نعجـة خليط (2/1فنلندى + 2/1حمـانى) وقسمت إلى أربعـة

مجموعات بكل مجموعة 10 نعاج. المجموعة الأولى (مقارنة) تم تلقيحها طبيعيا ، بينما المجموعات المعاملة الأخرى عوملت هرمونيا ولقحت صناعيا. نعاج المجموعة الثانية حقنت بالعضل بـ 4 ميكروجم Buserelin وفـى اليـوم السـابع 175 ميكـروجم كلوبروستينول ثم فـى اليـوم التاسـع بـ 4 ميكـروجم Buserelin مهبلية 45 ملجم لمدة 11 يوم ، أما نعاج المجموعة الرابعة فقد تم معاملتها بتركيب CIDR مهبليا لمدة 11 يوم. نعاج الجموعنين الثالثة والرابعة تم حقنهما بـ 600 وحدة دولية PMSG قبل 48 ساعة من نزع الاسفنجات أو CIDR ثم حقنت 175 ميكروجم كلوبروستينول فى اليوم الـ11 وهو يوم النزع ثم لقحت صناعيا على وقت محدد بعد 52 ساعة من النزع.

أظهرت النتائج حدوث مظاهر شبق بنسبة 30\% فى نعاج المعاملة الثانية و 100\% لكل من نعاج المعاملتين الثالثة والرابعة. وكان حدوث الثبق مبكرا فى نعاج المعاملة الثالثة عن كلا المجموعتنين الثنانية والرابعة. كانت مدة ظهور الثبق متمانلة فى كل من نعاج المعاملات الثناثة. كان معدل الولادات منماثل بين المجموعة المقارنة والمجموعتين الثالثة والرابعة (70\% لكل منهما) وبفروق معنوية عالية عن المجموعة الثانية (50\%).

توصى الدراسة بتظظيم الثبق فى النعاج خلال موسم تتاسل مايو باستخدام الاسفنجات المهبلية او CIDR مع حقن PMSG قبل 48 ساعة من النوع وحقن بروستاجلاندين يوم النزع حيث انها تحدث تتظيم جيد للثبق مع ولادات مبكرة منظمة وبذللك يتحقق زيادة للعائد الاقتصادي وزيادة كفاءة خصوبة

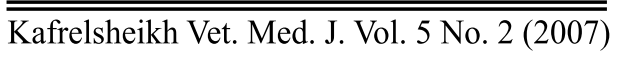

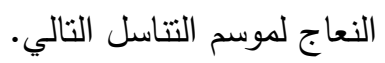

